\title{
Factors Contributing to Halal Food Fraud in Selangor
}

\author{
Nurzahidah Jaapar ${ }^{1}$, Umi Hani Abdul Razak ${ }^{2}$, Anis Husna Abdul Halim ${ }^{3}$, Fairuzah Basri ${ }^{1}$ \\ 1 Academy of Contemporary Islamic Studies (ACIS), \\ Universiti Teknologi MARA Shah Alam, 40450 Shah Alam, Selangor Malaysia \\ 2 Head of Centre of Academic Development (CADe) \\ Kolej Space, Tingkat 2 (Podium), No.8, Jalan Maktab, 54000 Kuala Lumpur, Malaysia \\ 3 Postgraduate student, Academy of Contemporary Islamic Studies (ACIS), \\ Universiti Teknologi MARA Shah Alam, 40450 Shah Alam, Selangor Malaysia
}

nurzah8883@uitm.edu.my, ummihani@kolejspace.edu.my, anishusna@gmail.com, fairuzah613@uitm.edu.my Tel: 019-3670299

\begin{abstract}
This paper attempted to explore the factors that contribute to halal food fraud and possible methods to address this problem. This paper uses a qualitative research approach as well as in-depth interviews with the two enforcement officials from JAIS and KPDNHEP. Based on the interviews, the researcher found that two key factors contributing to halal food fraud are lack of knowledge and halal as a marketing tool. After observing the factors, the researchers hypothesize solutions to the halal fraud epidemic. The study will help to improve the halal industry by solving all halal problems.
\end{abstract}

Keywords: Halal Industry, Food, Fraud, Selangor

eISSN: 2398-4287O 2021. The Authors. Published for AMER ABRA cE-Bs by e-International Publishing House, Ltd., UK. This is an open access article under the CC BYNCND license (http://creativecommons. org/licenses/by-nc-nd/4.0/). Peer-review under responsibility of AMER (Association of Malaysian Environment-Behaviour Researchers), ABRA (Association of Behavioural Researchers on Asians/Africans/Arabians) and cE-Bs (Centre for Environment-Behaviour Studies), Faculty of Architecture, Planning \& Surveying, Universiti Teknologi MARA, Malaysia.

DOI: https://doi.org/10.21834/ebpj.v6iSl6.3118

\subsection{Introduction}

Allah, the Exalted, has made it obligatory for Muslims to eat properly in the world (al-Qaradawi, 1980). These two aspects, namely halal and best quality, guarantee physical health and vigilance and are a push factor that helps to improve the quality of taqwa towards Allah (Adam Drahmani \& Suhaimi Ab. Rahman, 2019). Halal is a term in Islamic jurisprudence that indicates that a product is justified, acceptable and safe and of the highest quality (Muhamad 'Uqbah, 2000; Jayyib S.A, 1998). However, with the introduction of new technologies, more and more new chemical ingredients are being synthesized (Asnidar Hanim Yusuf, S. A., 2016). This situation has raised concern among Muslim consumers whether certain ingredients have been mixed with non-halal ingredients (Hanifar bin Sulaiman, 2016).

Halal has become a remarkable trend in Malaysia and around the world. The halal market has a significant impact on the industry players who make halal certification a tool to attract people to buy the product (Krishnan, W. H., 2018). The use of halal terminology needs to be monitored by the authority to ensure the integrity of the halal industry (Zakaria, Z., \& Ismail, S. Z., 2014). Despite the lack of separate halal legislation, many supporting laws support the implementation and enforcement of halal, including the Trade Description Act 2011, the Food Act 1983, and the Animal Act 1953 (revised 2006) (Ministry of Standards, Malaysia, MS1514:2009).Furthermore, the halal industry is a sector that has not been fully explored and has strong growth potential for the future (Jaapar et al., 2021). According to the global community, more Muslims will be living in the world by 2021 (https://www.worldometers.info/, 2021). Although there are some national and global concerns about the halal sector, it is important to note that the halal logo itself is often misused by criminals (Mustafa et al, 2014). Despite the growth of the halal sector, the Muslim community still faces serious problems such as lack of formal halal 
certification, non-Islamic processing of food, unclear food contents, and cleanliness (Amiratul Munirah Yahaya \& Zulaipa Ruzulan, 2020). In this study, we will investigate the factors that contribute to halal food fraud and their solution. The study will help to improve the halal industry by solving all halal problems.

\subsection{The Concept of Fraud from Islamic Perspectives}

Halal certifications are required at the retail and wholesale levels for a variety of foods. Halal goods are often indistinguishable from nonhalal goods, making it difficult indeed for customers to determine the origin of their goods. Fraud can be understood as something that is not what it appears to be and is deliberately used to deceive people, especially to get money (Wahbah Zuhaili, 1989).

Food fraud has been defined by Spink and Moyer (2011) as the intentional substitution, addition, misuse, or misrepresentation of food, food ingredients, or even food packaging with misleading claims on product labeling designed to make easy money with minimal financial risk while maximizing profits and minimizing losses. In contrast to the present study, a recent study by Jaswir et al (2016) found that food fraud or food adulteration consists of substituting expensive and costly ingredients with inferior and cheap ingredients that are readily available in the market. According to Elliot (2018), food fraud is any act done by businesses or individuals to deceive other businesses and individuals, whether through misrepresentation or not. Thus, it can be considered that food fraud is the deception of customers using food products, ingredients, and packaging for economic gain, involving substitute products, unauthorized alterations, misbranding, counterfeiting, stolen goods, or other forms of commercial crime (Abdul Jabbar, 2012).

According to Siti Sara \& et al (2013), the terms fraud, accident and gross deception are used interchangeably in Islamic legal texts to refer to fraud. Taghrir (fraud) refers to the deception of others using false means represented as actual actions or words to induce the other to engage in a transaction that he would not have engaged in but for the use of those means (Wahbah Al-Zuhaili, 1989). In this sense, taghrir can be either a stereotypical behavior or a comment (Siti Sara et al, 2013). According to Islamic jurisprudence, deception is a grave moral fault, as it is stated in the Qur'an, "Woe to those who commit deception, to those who, when they receive from men by measure, demand the full measure, but when they have to give to men by measure or weight, give less than is due to them". Do they not believe that on the great Day of Judgment before the Lord of the world they will be held accountable for their deeds?". Islam condemns those who are subjected to mistreatment. This includes those who cannot be measured directly.

Many Muslim scholars approve of a contract that involves low risk because their definition of gharar is limited to the degree of risk or ambiguity (Nehad \& Khanfar, 2016). The paper concludes that gharar (uncertainty) in Islam refers to any exchange of uncertain items whose identity or desirability is unknown due to the uncertainty of the outcome of the contract and the quality of the subject matter of the contract (Uddin \& Akhter, 2015). Gharar is distinguished into excessive gharar (gharar fahish) and minor gharar (gharar yasir) (Majallat alAhkam al-'Adliyyah, 1968). There are many examples of gharar fahish in contracts, and it usually occurs when gharar sales are prohibited by Islamic law. On the other hand, the ambiguity that is always present in all contracts and actions is also accepted and tolerated (Nehad \& Khanfar, 2015).

\subsection{Methodology}

This study attempts to examine the factors that contribute to halal food fraud in Selangor. A qualitative approach is used, and interviews were conducted with the two senior enforcement officers from JAIS and KPDNHEP who were involved in investigating halal food fraud especially in Selangor. The data for this study is based on 2 semi-structured interviews conducted with these informants in face-to-face discussions related to the halal industry and the reported case of halal fraud in Selangor. In addition, journal articles, statutes, legal reports, websites and figh references were also examined to achieve the research objectives. The interviews were then transcribed and analyzed. Content analysis was used to conduct the analysis. Hsieh and Shannon (2005) define content analysis as "a research method for subjectively interpreting the content of textual data through the systematic classification process of coding and identifying themes or patterns". In this study, the data from the interviews and other sources such as websites and brochures were categorized according to the different practices identified from the interview data that relate to fraud in the halal food industry based on the Trade Description Act 1975 and 2011. Purposive sampling was used to select the sample as the researcher found that these products are among the most frequently complained and reported problems by consumers. The summary of all the responses to the interview questions was divided into subsections which are presented in the next section.

\subsection{Findings and Discussions}

The government oversees the halal industry to ensure consumer protection. When the halal industry was supervised, certain problems arose, such as shoplifting. Halal food fraud has occurred in the halal industry and traders have used this to gain consumer attention. The 
Department of Domestic Trade and Consumer Affairs (KPDNHEP) has a proven track record of detecting halal food fraud. A KPDNHEP official said.

"Since 2011, about 30 cases related to Halal have been recorded till date.

(KPDNHEP officer)

There are many cases of halal abuse in the industry. The JAIS officer mentioned that they have received over 500 complaints of halal food fraud in 2019. The JAIS officer stated:

"These cases included the mixing of raw materials between halal and non-halal (40 cases), slaughterhouses (80 cases), use of expired halal logo/use of the fake halal logo (63), halal debates (21 cases). confirming certificate status of Malaysian halal certification (40 cases), Ramadhan buffets (17 cases), displaying Quranic verses in business premises (311 cases) and displaying the halal certificates of other companies (23 cases)."

The case studies presented by JAIS are worrying because halal food fraud is widespread and concern about the issue is high. The issues are worrying as they can jeopardize halal compliance and violate consumers' rights. KPDNHEP also pointed out that mislabelling goods or services as halal is an equally common form of halal food fraud.

\subsection{Factors contributing to Halal Food Fraud}

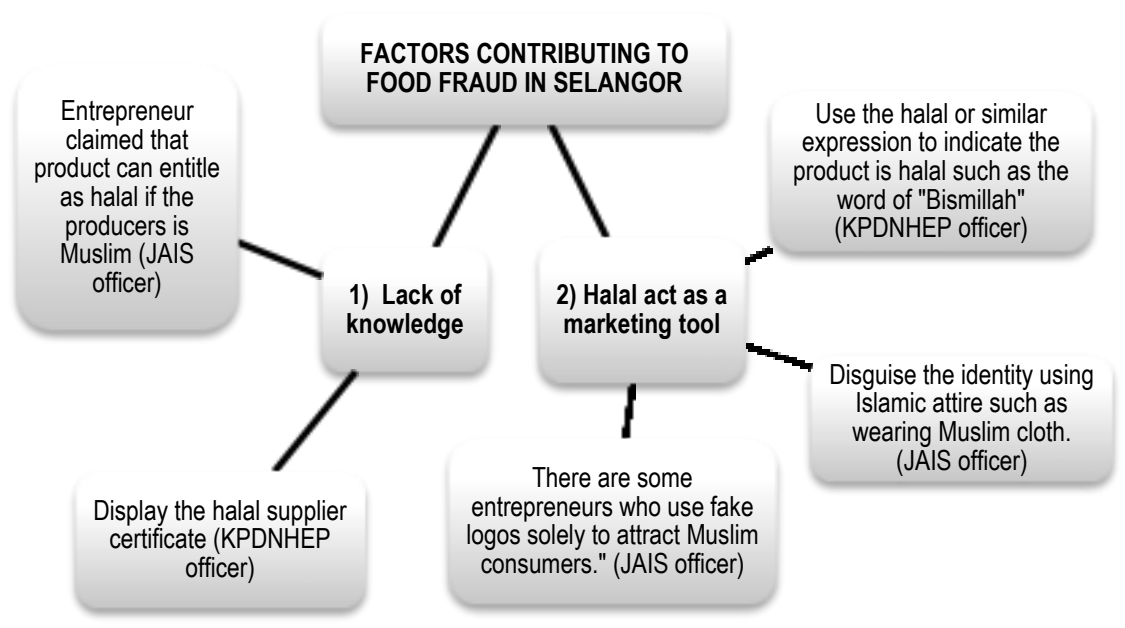

Fig. 1: Factors contributing to halal food fraud in Selangor Source: Researcher, (2020)

Firstly, some of the entrepreneurs lack awareness and knowledge about Halal. There are businessmen who have less information about halal regulations. said a KPNDHEP officer:

"Some believe that if a raw material supplier has a halal certificate, he can use the halal logo on his product. This assumption is wrong because all products that undergo a new process, such as new packaging, must submit a halal application if they want to use the halal logo on their product."

(KDNHEP officer)

One cannot simply use the halal certificate of the supplier if he does not have a valid halal certificate for his product or business. The person must apply for a new halal certificate if he wants to use a halal logo (Anidar, 2016). After a person's application is approved by JAKIM, he can use the halal certificate to market and promote the halal logo. The function of using a halal logo is that they are free to use the halal logo to promote their product without violating the Trade Descriptions Act 2011. However, it turns out that the business owner is not familiar with the proper implementation of halal certification of the business. Some traders or entrepreneurs advertise goods that are halal certified even though they do not have the certificate themselves. This finding indicates that the entrepreneur does not understand the halal process.

"They claim that Muslims are entitled to use the halal logo if Muslims make the product. Some even think that if suppliers already have halal certificates, they can put the halal logo on their products."

(JAIS officer)

There is a lack of knowledge about the problems halal poses for small business owners. Even if the production methods of the product are Muslim, the products themselves may not be halal compliant. People are unable to distinguish halal certification from standard certification and therefore label their product as "halal". The halal logo that is not accompanied by the halal application may violate the law 
on trade description. Some manufacturers use halal logos to mass market their products. Consumers who lack information about halal may gain an advantage in taking it.

Secondly, some of the entrepreneurs consider halal only as an added value and a tool to market their products. Many entrepreneurs use the halal logo as one of their marketing strategies, so in their opinion, there is no need to maintain the credibility of halal. They use a fake halal logo or label on the product packaging and ignore the halal status of the product.

"Moreover, most of the entrepreneurs make this halal logo one of the marketing methods, so there is no need to maintain halal integrity. Therefore, some entrepreneurs use fake logos only to attract Muslim consumers."

(JAIS officer)

Some companies use a fake halal certification on their products to deceive consumers who do not want to disclose their religious beliefs. ndependent companies are trying to create their halal brand. The entrepreneur's use of Islamic or Arabic terms as a marketing tactic promotes their products.

"... examples include using the word 'Bismillah' at the Mamak stall even though the owner is not Muslim. This will confuse the Muslim customers."

(KPDNHEP officer)

Unfortunately, the halal claim can cause big problems if the business owner is not Muslim but claims halal products. The company mentions Arabic or Islamic in the labeling to give the impression that it is for Muslims. Another case of Halal as a marketing tool discussed by the JAIS officer:

"At halal debates, the Mamak stalls hang Quranic verses in their booths and wear Muslim-looking clothes even though they are not Muslims. In Selangor, any restaurant or hotel that does not have a halal certificate is not allowed to offer a 'Ramadan buffet' during the fasting period."

(JAIS officer)

There are still several issues related to halal food fraud which show that some irresponsible companies use all the elements that show that their product is a halal brand. There are many cases of halal fraud and abuse, mainly because traders do not have sufficient halal knowledge and use the halal term or a similar term for their marketing tools.

\subsection{Suggestion to eradicate halal food fraud in Selangor}

It is impossible to reduce halal food fraud to zero because there are many parties involved. However, some changes are significant for the development of the halal industry. Overall, the improvement of the halal industry in eradicating halal problems is suggested based on the concerns expressed by the informant. The researcher makes suggestions based on the situation to solve or reduce the problems of halal food fraud in Malaysia.

\subsection{Educating traders and consumers}

"Consumers and traders need to be aware of the concept of halal."

(KPDNHEP officer)

"We need to educate the shopkeepers, especially those who live in the village, and the customers. So, they are aware of their right as consumers not to be confused by the halal scam."

(JAIS officer)

Usually, the main factors leading to food safety problems are a lack of consumer awareness. Therefore, the KPPDNHEP officer suggested that they should be educated about Halal so that they know their rights as consumers and not be confused by fraudsters selling Halal food. It is well established that traders lack knowledge when they use statements indicating that the product is halal, while consumers who lack knowledge can easily be deceived because they do not fully understand the concept of halal. Authorities should do more to educate the general population about the importance of following Islamic religious rules. Consumers and traders in Malaysia should be aware of the halal law and how it operates. Relevant parties must be educated on the Halal Law in order to guarantee that they are aware of the proper methods and mechanisms that are necessary to distinguish between right and wrong. Therefore the close and continuous cooperation and our collaboration with the Halal Authority to educate on Halal concerns and prevent Halal food fraud should be in line with consumer awareness and appreciation of the importance of halal in their lives.

\subsection{Expanding the number of enforcing officers}

"At the same time, the number of enforcement officers is still insufficient to handle all incidents of halal fraud." If you're looking for a unique"

(JAIS officer)

Since many personnel is required to monitor and manage all aspects of halal, it is also important to extend the team to handle all circumstances. Inadequate inspection and investigation, as well as efficient enforcement, are hampered by a lack of human resources. More enforcement personnel should be appointed to the MAIN (Majlis Agama Islam Negeri) or JAIN (Jabatan Agama Islam Negeri) agency 
in each state to assist the current number of officers is insufficiency. adding a halal enforcement officer would considerably increase enforcement efficiency.

\subsection{Strengthen the Trade Description Act}

The major statute to combat halal food fraud is the Trade Description Act of 2011. It was possible to keep track of and control halal activities such as halal certification and halal marking. KPDNHEP's position on halal food fraud is as follows:

"The TDA Act has been sufficient in controlling the issue of halal fraud in the country, but if a continuing need arises, management will propose an amendment to the Act to guarantee that the legislation stays relevant to contemporary developments."

(KPDNHEP officer)

Aside from that, the JAIS officer added that the act should increase halal food fraud inspection and enforcement: "Other than that, the implementation of the act itself needs to be strengthened as so far there are not many cases that could be convicted".

(JAIS officer)

The Trade Description Act of 2011, which specifies how halal items must be branded and marked as halal, applies to the halal food fraud issue. The orders also detail the progress made in addressing the problem of halal food fraud. To be able to service all halal customers, however, both quantity and quality are required. TDA 2011 will need to be updated in the future to reflect the halal business. Aside from the two orders, the Trade Description Act (Definition of Halal) and Trade Description (Certification and Marking of Halal) Order 2011, the TDA 2011 attempts to propose new ways to address other halal crimes (Zalina Zakaria \& Siti Zubaidah, 2014).

\subsection{Conclusion}

Muslim consumers are concerned about halal food fraud. The factors that lead to fraudulent halal transactions are the subject of this study. The study's research questions and objectives were created, and data was gathered. The study discussed the reasons for religious deception as well as how halal might be used as a marketing strategy. To effectively combat halal food fraud, consumers must be educated, the number of enforcement officials must be increased, the Trade Description Act 2011 must be strengthened, and criminals must be prosecuted more easily. To properly handle the issue of halal food fraud, government measures should be increased. Hence, future research should expand the prevalent factors of fraud in the halal industry from the point of view of food entrepreneurs to assess the attitude and behavior of halal food entrepreneurs in Selangor.

\section{Acknowledgments}

The authors highly appreciate the funding and support from the Research Nexus UiTM (ReNeU), Office of Deputy Vice Chancellor (Research and Innovation), Universiti Teknologi MARA, 40450 Shah Alam, Selangor under the MEE program (Mentor, Enforce \& Execute).

\section{Paper Contribution to Related Field of Study}

This paper contributes to the halal business and management.

\section{References}

Adam Drahmani \& Suhaimi Ab. Rahman (2019), Konsep dan Aplikasi Hisbah Dalam Perniagaan Produk Halal, Journal of Fatwa Management and Research, Vol 18 , No. 1. www.jfatwa.usim.edu.my.

Al-Qaradawi, Yusof (1980), al-Halal wa al-Haram fi al-Islam, Kaherah: Maktabah al-Wahbah.

Amiratul Munirah Yahaya \& Zulaipa Ruzulan (2020), Quranic Concept of Halalan Tayyiban and its Application in Food and Beverages of Hospitality Sector in Malaysia, Journal Contemporary Islamic Studies, Vol 6 (1), 2020

Asnidar Hanim Yusuf, S. A. (2016). Halal Certification vs Business Growth of Food Industry in Malaysia. Journal of Economics, Business and Management.

Hanifar bin Sulaiman. (2016). Portal Rasmi MyHealth Kementerian Kesihatan Malaysia. Retrieved from Pakaian Pengendali Makanan Mengikut Kehendak UndangUndang Kesihatan: http://www.myhealth.gov.my/pakaian-pengendali-makananmengikut-kehendak-undang-undang-kesihatan/

Hsieh, H.F. and Shannon, S.E. (2005), "Three approaches to qualitative content analysis", Qualitative Health Research, Vol. 15 No. 9, pp. $1277-1288$.

Jaapar, N.., Mohamed Yusof, M. F., Mohd, M. D., \& Syed Abdullah, S. F. (2021). Exploring the Application of Islamic Legal Maxims in Advertising: Practices of manufacturers. Environment-Behaviour Proceedings Journal, 6(SI5), 95-104. https://doi.org/10.21834/ebpj.v6iSI5.2942

Krishnan, W. H. (2018). The Preferences of Muslim Consumers' Behaviour on Halal Food based on the Utility Maximization Theory. International Journal of Engineering \& Technology, 37-39. 
Jaapar, N., et.al. / International Virtual Colloquium on Multi-disciplinary Research Impact (1st Series), Shah Alam, Malaysia, 15 Oct 2021, E-BPJ, 6(SI6), Oct 2021 (pp.39-44)

Muhamad 'Uqbah, An Nafiq (2000), Halal dan Haram dalam Pemakanan, Kuala Lumpur, Darul Nu’man.

Mustafa' Afifi Ab. Halim \& Azlin Alisa Ahmad (2014). Enforcement of Consumer Protection Laws on Halal Products: Malaysian Experience, Asian Social Science; Vol. 10, No.

Nehad, A., \& Khanfar, A. (2016). A critical analysis of the concept of gharar in Islamic financial contracts: a different perspective. Journal of Economic Cooperation \& Development, 37(1), 1.

Siti Sarah Ibrahim, Man, N. C., \& Noor, A. M. (2013). Fraud: An Islamic Perspective. In The 5th International Conference on Financial Criminology (ICFC).

Spink, J., \& Moyer, D. C. (2011). Defining the public health threat of food fraud. Journal of food science, 76(9), R157-R163.

Tongco, M. D. C. (2007). Purposive Sampling as a Tool for Informant Selection. 158, 147-158.

Uddin, M. A. (2015). Principles of Islamic finance: Prohibition of riba, gharar and maysir. https://mpra.ub.uni-muenchen.de/id/eprint/67711

Zakaria, Z., \& Ismail, S. Z. (2014). The Trade Description Act 2011: Regulating, Halal" in Malaysia. 2011-2013.

Websites:

Trade Description Act 2011, https://www.wipo.int/edocs/lexdocs/laws/en/my/my068en.pdf.

World Population, https://www.worldometers.info/ 